\title{
Stiff-person syndrome with rhabdomyolysis
}

\author{
Toshiyuki Nakanishi, ${ }^{1}$ Tsuneaki Kenzaka (1) 2,3
}

${ }^{1}$ Department of Internal Medicine, Nerima Hikarigaoka Hospital, Nerima-ku, Tokyo, Japan

${ }^{2}$ Division of Community Medicine and Career Development, Kobe University Graduate School of Medicine, Kobe, Hyogo, Japan ${ }^{3}$ Department of Internal Medicine, Hyogo Prefectural Tamba Medical Center, Tamba, Hyogo, Japan

\section{Correspondence to} Dr Toshiyuki Nakanishi; r060eb@gmail.com

Accepted 23 November 2021

Check for updates

(C) BMJ Publishing Group Limited 2021. No commercial re-use. See rights and permissions. Published by BMJ.

To cite: Nakanishi T, Kenzaka T. BMJ Case Rep 2021;14:e246147. doi:10.1136/bcr-2021246147

\section{DESCRIPTION}

A 52-year-old woman presented with episodic stiffening of her back and thighs every 3 months for 5 years. The sudden stiffness had worsened and resulted in multiple falls 3 years before admission. She became shut-in due to fear of falling and being unable to walk without using a cane. She was alert, although episodic spasms were induced repeatedly by sudden touch, noise and light. As she was on a selective serotonin reuptake inhibitor (SSRI) regimen and had a fever, diaphoresis and elevated serum creatine kinase (CK) $(16200 \mathrm{U} / \mathrm{L})$, a working diagnosis of neuroleptic malignant syndrome (NMS) complicated by rhabdomyolysis was made, necessitating referral to our care facility for further examination. Physical examination revealed severe lumbar lordosis and muscle stiffness in her lower limbs, bilaterally (video 1 ). Blood tests revealed an extremely high level $(>2000 \mathrm{U} / \mathrm{mL})$ of antiglutamic acid decarboxylase antibodies, and her cerebrospinal fluid contained oligoclonal bands. These findings led to the final diagnosis of stiffperson syndrome (SPS). Initially, under the tentative diagnosis of NMS, the patient had not showed any improvement with SSRI cessation and intravenous dantrium. However, after the SPS diagnosis was made, she was given plasma exchange and intravenous immune globulin, and subsequently commenced on oral diazepam, which was tapered gradually. Finally, she was able to walk without any difficulty or anxiety.

SPS is an adult-onset central nervous system disorder caused by an autoimmune reaction. ${ }^{1}$ In SPS, episodic spasms are induced by sudden stimuli, which cause progressive muscle stiffness of the limbs and trunk, resulting in impaired ambulation. ${ }^{2}$ In the early stages of SPS, the spasms can cause lumbar lordosis and falls, which often lead to social phobia and anxiety. ${ }^{3}$ If the patient has been taking psychiatric medications, clinicians may misdiagnose the

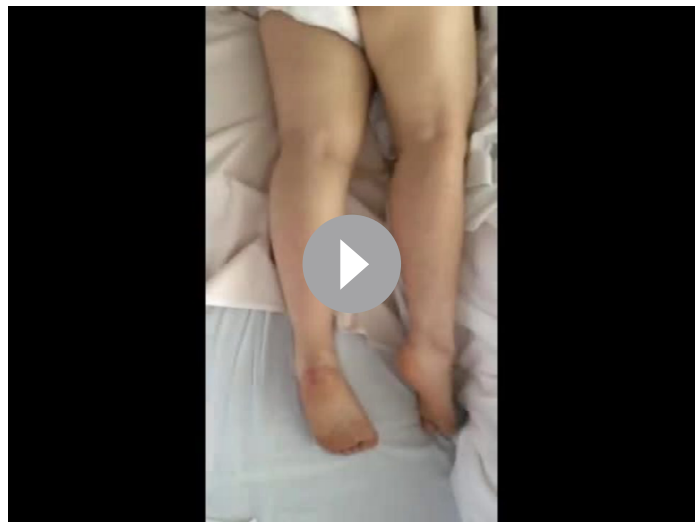

Video 1 Episodic spasms in stiff-person syndrome.

\section{Patient's perspective}

I appreciate the fact that I was finally diagnosed and received definitive treatment. I asked the doctor, Toshiyuki Nakanishi, to spread the clinical knowledge of this rare disease, stiff-person syndrome, and strongly believe that many of those who are suffering from stiff-person syndrome would also be diagnosed and treated properly.

\section{Learning points}

Stiff-person syndrome (SPS) is often misdiagnosed as a psychiatric disorder, such as neuroleptic malignant syndrome or serotonergic syndrome, if an affected patient has been taking psychiatric medication.

- SPS should be considered for patients who have muscle spasms, in the presence of antiglutamic acid decarboxylase antibodies.

- This case illustrates the importance of checking other parameters in addition to creatine kinase levels.

condition as a psychiatric disorder, such as NMS or serotonin syndrome (SS). Although serum CK levels can be elevated in the late stages of SPS, because the muscle spasms can be severe enough to cause muscle breakdown, ${ }^{4}$ a distinguishing indicator for SPS diagnosis is that serum CK levels are usually lower than that in other aforementioned disorders. To the best of our knowledge, only two other cases of SPS with concurrent rhabdomyolysis have been reported. ${ }^{45}$

However, as in this case, SPS can mimic NMS and SS in that serum CK levels may be highly elevated. Based on a literature review, the median peak CK level was $10888 \mathrm{U} / \mathrm{L}$ in patients with SS $(\mathrm{n}=60)$ and $15059 \mathrm{U} / \mathrm{L}$ in patients with NMS $(\mathrm{n}=74)$, compared with $16200 \mathrm{U} / \mathrm{L}$ in our patient with SPS. ${ }^{6}$

Even in such cases, SPS should be considered when patients present with the characteristic muscle stiffness and spasms.

Contributors TN experienced the case. TN wrote the manuscript with support from TK.

Funding The authors have not declared a specific grant for this research from any funding agency in the public, commercial or not-for-profit sectors

Competing interests None declared.

Patient consent for publication Consent obtained directly from patient(s)

Provenance and peer review Not commissioned; externally peer reviewed. 
Case reports provide a valuable learning resource for the scientific community and can indicate areas of interest for future research. They should not be used in isolation to guide treatment choices or public health policy.

\section{ORCID iD}

Tsuneaki Kenzaka http://orcid.org/0000-0002-3120-6605

\section{REFERENCES}

1 Baizabal-Carvallo JF, Jankovic J. Stiff-Person syndrome: insights into a complex autoimmune disorder. J Neurol Neurosurg Psychiatry 2015;86:840-8.
2 Meinck H-M, Thompson PD. Stiff man syndrome and related conditions. Mov Disord 2002;17:853-66.

3 Henningsen $\mathrm{P}$, Meinck H-M. Specific phobia is a frequent non-motor feature in stiff man syndrome. J Neurol Neurosurg Psychiatry 2003;74:462-5.

4 Gangadhara S, Gangadhara S, Gandhy C, et al. Rhabdomyolysis and autoimmune variant stiff-person syndrome. Clin Pract 2016;6:117-8.

5 Petzold GC, Marcucci M, Butler MH, et al. Rhabdomyolysis and paraneoplastic stiff-man syndrome with amphiphysin autoimmunity. Ann Neurol 2004;55:286-90.

6 Kruijt N, van den Bersselaar LR, Wijma J, et al. Hyperckemia and rhabdomyolysis in the neuroleptic malignant and serotonin syndromes: a literature review. Neuromuscul Disord 2020;30:949-58.

Copyright 2021 BMJ Publishing Group. All rights reserved. For permission to reuse any of this content visit

https://www.bmj.com/company/products-services/rights-and-licensing/permissions/

BMJ Case Report Fellows may re-use this article for personal use and teaching without any further permission.

Become a Fellow of BMJ Case Reports today and you can:

- Submit as many cases as you like

- Enjoy fast sympathetic peer review and rapid publication of accepted articles

- Access all the published articles

Re-use any of the published material for personal use and teaching without further permission

\section{Customer Service}

If you have any further queries about your subscription, please contact our customer services team on +44 (0) 2071111105 or via email at support@bmj.com.

Visit casereports.bmj.com for more articles like this and to become a Fellow 